\title{
STUDI MORFOMETRI DAN TINGKAT HERBIVORI DAUN MANGROVE DI SEGARA ANAKAN CILACAP
}

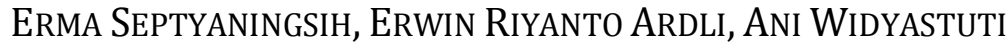

Fakultas Biologi, Universitas Jenderal Soedirman, Jalan dr. Suparno 63 Purwokerto 53122

\section{A B S T R A C T}

Mangrove communities are part of the natural coastal ecosystems that have a vital role, such as the greatest source of organic material for the surrounding aquatic environment. A variety of ecological phenomenon often happens recently, either directly or indirectly affects the change of mangrove vegetations. Leaf is one of the plant organs that change shape according to the condition of the mangroves and the aquatic environment where the plant lives. The common changes of the leaves are the symmetry (morphometry), the size, and the shape. Mangrove leaves are also subjected to herbivory (predation), that will result in reduced leaf area of the photosynthesis and lowered the production of organic matter to the surrounding waters. This research aimed to determine the morphometric variation and herbivory rates of mangrove leaves at Segara Anakan Cilacap. Mangrove samples were Aegiceras corniculatum, Avicennia marina, Ceriops tagal, Rhizophora apiculata, and Sonneratia caseolaris. The study used survey method with stratified random sampling technique. The results showed morphometric variations of the five species were three variations, while the average herbivory rate from highest to lowest were: Avicennia marina (7.46\%), Sonneratia caseolaris (6.91\%), Rhizophora apiculata (4.08\%), Aegiceras corniculatum (3.42\%) and Ceriops tagal $(3.00 \%)$. The difference of age and species of leves affected the herbivory level.

KEY WORDS: morphometry, herbivory, leaf age, mangrove, Segara Anakan Cilacap

Corresponding Author: ERWIN RIYANTO ARDLI | email: erwin.ardli@unsoed.ac.id

\section{PENDAHULUAN}

Hutan mangrove atau mangal adalah sebutan umum yang digunakan untuk menggambarkan satu varietas hutan pantai yang didominasi oleh pohon-pohon yang khas atau semak-semak yang mempunyai kemampuan untuk tumbuh dalam perairan asin (Nybakken, 1992). Saenger (2002) menambahkan hutan mangrove sebagai tumbuhan litoral yang terlindung dari ombak yang besar dan umumnya tersebar di daerah tropis dan subtropis.

Segara Anakan merupakan suatu ekosistem mangrove dengan sebuah laguna di Pantai Selatan Pulau Jawa. Terletak pada koordinat $07^{\circ} 34^{\prime} 29,42^{\prime \prime} \mathrm{LS}-$ $07^{\circ} 47^{\prime} 32,39^{\prime \prime} \mathrm{LS}, \quad 108^{\circ} 46^{\prime} 30,12^{\prime \prime} \mathrm{BT}-109^{\circ} 03^{\prime} 21,02^{\prime \prime} \mathrm{BT}$. Secara administratif, Segara Anakan terletak di Kecamatan Kampung Laut Kabupaten Cilacap dengan luas wilayah Segara Anakan mencapai 34.018 ha (Ardli et al., 2010).

Berbagai fenomena ekologi yang sering terjadi belakangan ini baik secara langsung maupun tidak langsung mempengaruhi perubahan vegetasi mangrove. Daun merupakan salah satu bagian tumbuhan yang mengalami perubahan bentuk sesuai kondisi "kesehatan" mangrove dan lingkungan perairan tempat hidupnya. Contoh tipe perubahan bentuk daun mangrove yang biasa dijumpai antara lain perubahan kesimetrisan (morfometri) daun (Nurakhman, 2002). Morfometri adalah suatu bidang yang berhubungan dengan variasi dan perubahan di dalam wujud (ukuran dan bentuk) dari organisme atau objek (Borozan dan Babac, 2003). Morfometri daun didefinisikan sebagi rasio lebar dan panjang daun (Lugo, 1978 dalam Barret dan Rosenberg, 1981). Variasi rasio morfometri dapat menggambarkan kondisi/ kualitas vegetasi mangrove setempat (Barret dan Rosenberg, 1981). Hal ini dikarenakan kondisi mangrove yang buruk dapat mempengaruhi variasi morfometri daun mangrove (Khusna, 2008). Selain itu, seperti halnya tumbuhan lain tidak lepas dari pengaruh herbivori. Murphy (1990) menjelaskan bahwa herbivori mangrove adalah eksploitasi secara langsung jaringan tumbuhan hidup oleh kepiting, moluska, dan serangga pada vegetasi mangrove. Proses herbivori daun, selain mempengaruhi pertumbuhan vegetasi juga akan mengurangi perannya sebagai produsen primer penghasil serasah daun dan oksigen.

Kandungan zat kimia dan palatabilitas pada daun akan mempengaruhi tingkat herbivori daun oleh herbivor. Onuf et al. (1977) menyatakan bahwa terjadinya herbivori merupakan respon dari herbivor terhadap nutrisi dan kandungan kimia yang terdapat di dalam daun. Sehingga tingkat herbivori juga dapat dijadikan indikator kondisi dan kesehatan vegetasi mangrove. Berdasarkan uraian tersebut di atas, penelitian ini bertujuan untuk mengetahui bagaimana variasi morfometri dan tingkat herbivori daun mangrove di Segara Anakan, Cilacap khususnya untuk melihat pengaruh spesies dan umur daun pada spesies A. corniculatum, A. marina, C. tagal, $R$. apiculata, dan $S$. caseolaris pada ekosistem mangrove Segara Anakan Cilacap

\section{METODA}

Metode penelitian yang digunakan adalah survey dengan teknik pengambilan sampel dilakukan dengan stratified random sampling, yaitu pengambilan sampel random dengan lapisan, dengan begitu diharapkan dapat menggambarkan keseluruhan sifat populasi atau sampel, mengetahui morfometri dan tingkat herbivori daun mangrove dengan perbedaan umur daun dan spesies (Khusna, 2008).

Parameter utama dalam penelitian ini meliputi panjang dan lebar daun untuk menentukan rasio morfometri daun, luas daun imajiner (utuh), luas daun yang tersisa, luas 
kerusakan, persentase herbivori. Sedangkan parameter pendukung dalam penelitian ini yaitu faktor lingkungan yang meliputi: suhu, nilai $\mathrm{pH}$ tanah, salinitas, jenis dan tekstur tanah, unsur hara, kandungan air dalam tanah, dan kandungan bahan organik.

Pengambilan sampel daun dilakukan pada spesies $A$. corniculatum, A. marina, C. tagal, $R$. apiculata, dan $S$. caseolaris. Titik pengambilan sampel dibuat pada tiap stasiun yang telah ditentukan sebanyak 3 titik mulai dari tepi (perbatasan antara perairan dengan daratan), kemudian masuk $50 \mathrm{~m}$ ke tengah, dan $50 \mathrm{~m}$ ke dalam. Hal ini dimaksudkan sebagai ulangan, sehingga tiap stasiun pengambilan sampel dilakukan sebanyak 3 ulangan. Adapun langkah-langkah pengambilan sampel daun adalah sebagai berikut:

a. Masing-masing spesies diambil sebanyak 5 tangkai yang dianggap bisa mewakili.

b. Seluruh daun dari 5 tangkai yang diambil kemudian dipetik semua kecuali yang masih kuncup kemudian dimasukkan ke dalam plastik, dibedakan tiap spesies.

c. Untuk pengukuran selanjutnya (pengukuran morfometri dan herbivori) diambil 5 daun secara acak dari tiap spesies per titik pada tiap stasiun.

Pengukuran morfometri daun mangrove dilakukan dengan cara scan leaf area, yaitu pengukuran luas area daun dengan menggunakan scanner sebagai alat bantunya. Hasil scanning daun diolah dengan menggunakan software Compu Eye-Leaf \& Symptom Area agar didapat hasil panjang dan lebar daun (tanpa tangkai) mangrove yang lebih akurat, baik yang utuh maupun daun yang rusak akibat herbivor.

Untuk pengukuran herbivori, maka daun dipisahkan berdasarkan umur (tua atau muda) dan kondisi daun (utuh atau rusak). Kategori kerusakan daun dibatasi dengan adanya bekas herbivori, yaitu hilangnya sebagian luasan daun akibat gigitan atau pelubangan. Untuk selanjutnya sama dengan pengukuran morfometri, yaitu dilakukan scan leaf area kemudian hasil scanning daun diolah dengan menggunakan software Compu Eye-Leaf \& Symptom Area untuk mendapatkan luas area daun (tanpa tangkai) mangrove yang lebih akurat, baik yang utuh maupun daun yang rusak akibat herbivor.

Populasi morfometri dilihat berdasarkan banyaknnya sebaran normal yang terbentuk pada grafik distribusi. Dalam penelitian ini grafik distribusi morfometri daun menggambarkan hubungan antara selang kelas morfometri daun (titik-titik pada sumbu x) terhadap persentase kumulatif (titik-titik pada sumbu y) (Khusna, 2008).

$$
\begin{gathered}
\text { Rasio morfometri }=\frac{\text { Panjang daun }}{\text { Lebar daun }} \\
\text { FR }=\frac{\text { Fn }}{\text { F Total }} \times 100 \% \\
\text { FK }=\text { FRn }+ \text { FR }_{\text {Jumlah FR sebelumnya }}
\end{gathered}
$$

Keterangan:

FR $=$ Frekuensi Relatif

FK = Frekuensi Kumulatif

$\mathrm{Fn}=$ Frekuensi rasio morfometri sampel ke $\mathrm{n}$

Selang kelas dibagi menjadi sepuluh bagian dengan kisaran nilainya di dapat dari nilai terendah sampai nilai tertinggi hasil perhitungan rasio morfometri. Frekuensi relatif adalah perbandingan antara frekuensi masing-masing kelas dengan jumlah frekuensi seluruhnya yang dinyatakan dalam persen. Frekuensi kumulatif merupakan penjumlahan dari frekuensi relatif ke-n dengan frekuensi relatif sebelumnya.
Koefisien Variasi (CV) digunakan untuk melihat kompetisi individual dan daya adaptasi yang dimiliki populasi mangrove berdasarkan pemencaran nilai-nilai morfometri daunnya. Koefisian variasi dihitung dengan menggunakan rumus (Nurakhman, 2002):

$$
\mathrm{CV}=\frac{\text { St. Dev }}{\mathrm{M}} \times 100 \%
$$

Keterangan:

CV (Coefficient variety $)=$ koefisien keragaman

$\mathrm{M}($ Mean $)=$ nilai rata-rata rasio morfometri daun

St.Dev = simpangan baku dari rasio morfometri

Untuk mengetahui hubungan antara panjang kali lebar dengan luas daun maka digunakan analisis regresi (Stowe, 1995). Berikut adalah rumusannya:

$$
Y=a+b x
$$

Keterangan:

Y : luas daun $\left(\mathrm{cm}^{2}\right)$

a : konstanta

$\mathrm{x}$ : (panjang x lebar)

b : koefisien $\mathrm{x}$

Perhitungan persentase luas daun yang hilang menurut Khusna (2008) adalah sebagai berikut:

$$
\frac{(\text { PLA }- \text { ALA })}{\text { PLA }} \times 100 \%=\% \text { Herbivori }
$$

Keterangan:

PLA = Luasan daun imaginer

ALA = Luasan daun yang tersisa

Taksiran luas daun yang dimangsa didapatkan dari selisih luas daun imaginer (PLA) dengan luas daun rusak yang tersisa (ALA). Persentase yang didapatkan kemudian diklasifikasikan berdasarkan persentase luasan daun yang hilang. Cooke, et al. (1984) dan Pribadi (1998) membagi tingkat herbivori ke dalam delapan kelas kerusakan sebagai berikut:

$$
\begin{aligned}
& \text { I }=<2,5 \% \\
& \text { II }=2,5 \%-5,0 \% \\
& \text { III }=5,1 \%-10,0 \% \\
& \text { IV }=10,1 \%-20,0 \% \\
& \begin{aligned}
\mathrm{V} & =20,1 \%-40,0 \% \\
\mathrm{VI} & =40,1 \%-60.0 \% \\
\mathrm{VII} & =60,1 \%-80,0 \% \\
\mathrm{VIII} & =>80 \%
\end{aligned}
\end{aligned}
$$

Untuk mengetahui hubungan pengaruh berbedaan stasiun pengambilan sampel terhadap tingkat herbivori daun maka dilakukan uji statistik dengan menggunakan uji $t$ untuk membandingkan dua kelompok dan uji $F$ untuk membandingkan tiga kelompok atau lebih.

\section{HASIL DAN PEMBAHASAN}

Segara Anakan merupakan suatu ekosistem mangrove dengan sebuah laguna pada bagian tengahnya. Segara Anakan terletak di Pantai Selatan Pulau Jawa, secara administratif masuk dalam wilayah Kecamatan Kampung Laut Kabupaten Cilacap. Segara Anakan mendapat pasokan air laut dari Samudera Hindia yang masuk ke dalam lagunanya melalui Plawangan Barat, sedangkan pasokan air tawar didapat dari tiga sungai utama yaitu Citanduy, Cibeureum, dan Cikonde serta sungai-sungai kecil di sekitarnya (Yuwono et al., 2007).

Hasil pengamatan terhadap daun-daun yang mengalami pemangsaan terlihat bahwa tipe-tipe kerusakan daun yang ditemukan berupa bekas pelubangan dan gigitan yang kerusakannya terletak 
pada pinggir daun, tengah daun maupun gabungan dari keduanya, dan pengelintingan daun. Ditemukan pula bekas pemangsaan yang bekas pelubangan dan gigitan tersebut masih menyisakan lapisan tipis transparan pada permukaan atas daun. Selain itu ditemukan pula beberapa herbivor di lokasi penelitian penelitian diantarannya serangga yang termasuk dalam ordo Coleoptera, Lepidoptera, Diptera, dan Hemiptera, serta berbagai macam gastropoda.

Dilihat dari hasil rata-rata rasio morfometri yang didapat masing-masing spesies $R$. apiculata memiliki nilai tertinggi yaitu 3,38 , kemudian diikuti oleh $A$. marina $(2,25), C$. tagal $(1,99), S$. caseolaris $(1,83)$, dan nilai terkecil pada $A$. corniculatum $(1,44)$ (Tabel 3.5). Sedangkan untuk nilai koefisen variasi yang memiliki nilai tertinggi yaitu A. marina (24,60\%), yang kemudian dibawahnya diikuti oleh $S$. caseolaris $(17,21 \%), A$. corniculatum $(16,72 \%), \quad$ R. apiculata (14,13\%), dan yang terkecil yaitu $C$. tagal $(12,58 \%)$.

Nilai koefisien variasi yang semakin besar menunjukkan bahwa suatu populasi memiliki nilainilai morfometri daun yang memencar dan dengan pemencaran tersebut, kompetisi antar individu dalam suatu populasi berkurang serta menunjukkan adanya daya adaptasi yang luas. Pada populasi yang bernilai koefisien variasi rendah menunjukkan suatu populasi memiliki nilai-nilai morfometri yang mengelompok. Pengelompokkan tersebut menyebabkan tingginya kompetisi antar individu dalam populasi tersebut dan menunjukkan daya adaptasi yang rendah dalam menghadapi lingkungannya. Nilai koefisien variasi dipengaruhi oleh letak suatu populasi dalam suatu zonasi, apakah di zona bagian dalam atau pada zona bagian luar (Khusna, 2008).

Untuk melihat variasi morfometri yang terbentuk maka distribusi morfometri daun dari ke lima spesies dimasukkan ke dalam grafik berikut (Gambar 1).

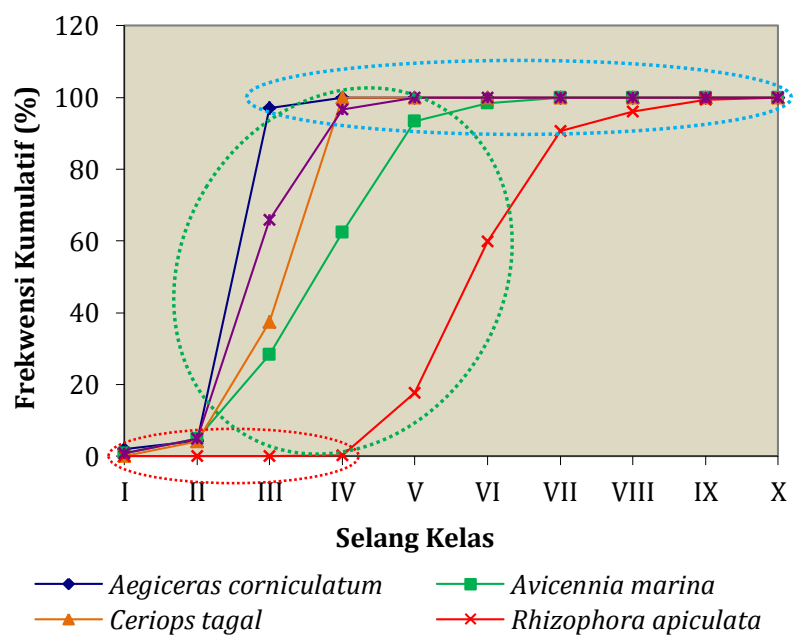

Gambar 1. Grafik Ogive Distribusi Morfometri Daun $A$. corniculatum, A. marina, C. tagal, R. apiculata, dan S. caseolaris di Lokasi Penelitian Segara Anakan, Cilacap

Variasi yang terbentuk pada morfometri daun $A$. corniculatum, A. marina, C. tagal, $R$. apiculata dan $S$. caseolaris dilihat dari nilai kumulatif dan selang kelas menunjukkan kecenderungan dalam 3 variasi semua (Gambar 1). Variasi pertama ditunjukkan dengan garis putus-putus warna merah, variasi kedua ditunjukkan dengan garis putus-putus warna hijau, dan variasi ketiga ditunjukkan dengan garis putusputus warna biru (Gambar 1).

Barret dan Rosenberg (1981) menyatakan bahwa jumlah variasi morfometri daun untuk kondisi lingkungan yang baik berkisar antara 1 dan 2 variasi. Semakin banyak jumlah variasi yang terbentuk mengindikasikan kondisi lingkungan yang kurang baik. Variasi morfometri daun daun digunakan sebagai parameter untuk melihat kondisi kesehatan mangrove. Jumlah variasi morfometri daun yang terbentuk menggambarkan tekanan lingkungan yang diterima oleh suati populasi mangrove. Semakin sedikit variasi morfometri yang terbentuk maka suatu populasi mangrove semakin sehat dan memiliki adaptasi dan ketahanan yang tinggi terhadap kondisi lingkungan yang kurang mendukung. keeratan korelasi antara luas daun dengan panjang kali lebar daun menurut Sudjana (1982) dalam Khusna (2008) menunjukkan korelasi tersebut sangat kuat karena nilai koefisien korelasi dari masing-masing spesies menunjukkan nilai antara 0,80-1,00.

Diduga sifat morfologi dan fisiologi tumbuhan akan mempengaruhi tingkat herbivori dan jenis pemangsa. Hadi et al. (2003) menjelaskan bahwa morfologi tanaman seperti ukuran daun, bentuk, warna, kekerasan jaringan tumbuhan dan adanya rambut menentukan seberapa jauh derajat penerimaan serangga terhadap tumbuhan tertentu.

Tabel 1. Rata-rata Tingkat Herbivori (\%) Per Satuan Luas Daun dan Rata-Rata Total Tingkat Herbivori Spesies Di Lokasi Penelitian Segara Anakan Cilacap

\begin{tabular}{lccc}
\hline Spesies & Daun Tua & Daun Muda & Rata-rata \\
\hline A. corniculatum & $2,52 \%$ & $4,35 \%$ & $3,42 \%$ \\
A. marina & $6,20 \%$ & $8,73 \%$ & $7,46 \%$ \\
C. tagal & $2,59 \%$ & $3,42 \%$ & $3,00 \%$ \\
R. apiculata & $2,81 \%$ & $5,35 \%$ & $4,08 \%$ \\
S. caseolaris & $5,60 \%$ & $8,23 \%$ & $6,91 \%$ \\
\hline
\end{tabular}

Tabel 1 menunjukkan bahwa persentase rata-rata tingkat herbivori tertinggi terjadi pada $A$. marina (7,46\%) dan terendah pada $C$. tagal $(3,00 \%)$. Urutan tingkat herbivori dari terendah hingga tertinggi antar spesies dalam penelitian ini adalah $C$. tagal $(3,00 \%)<$ A. corniculatum $(3,42 \%)<R$. apiculata $(4,08 \%)<S$. caseolaris $(6,91 \%)<A$. marina $(7,46 \%)$. Hal ini diduga dipengaruhi oleh kandungan tanin pada masingmasing spesies. Secara fisiologi kelima spesies memiliki dan memproduksi zat kimia (tanin) dengan kadar yang berbeda.Newberry dan de Foresta (1985) menyatakan bahwa jaringan tumbuhan akan sulit dicerna karena keberadaan tanin. Tumbuhan yang memiliki kandungan tanin lebih rendah akan mengalami tingkat herbivori lebih tinggi. Menurut Kathiresan (1992), C. tagal memiliki kandungan tanin paling tinggi $(16,78 \mathrm{mg} / \mathrm{g})$ sedangkan $A$. marina memiliki kandungan tanin paling rendah $(5,54 \mathrm{mg} / \mathrm{g})$ dibanding spesies lain dalam penelitian ini. 
Selain itu jarak antar pohon mempengaruhi tingkat herbivori. Hal ini sesuai dengan pendapat Johnstone (1981) yang menyatakan bahwa tingginya aktivitas herbivor terjadi pada kepadatan vegetasi yang lebih rendah karena herbivor tidak bisa menyebar dari vegetasi tersebut dan herbivor memerlukan banyak energi untuk menyebar luas. Faktor ketinggian juga akan mempengaruhi penyinaran kandungan nutrisi dalam daun. Hal ini dikarenakan tumbuhan yang lebih tinggi akan mendapatkan sinar matahari paling optimal dibandingkan dengan tumbuhan yang lebih rendah.

Secara umum persentase herbivori daun muda lebih tinggi jika dibanding dengan daun tua untuk semua spesies. Persentase herbivori paling tinggi terjadi pada daun muda $S$. caseolaris $(8,23 \%)$, sedangkan paling rendah terjadi pada daun tua $A$. corniculatum (2,52\%) (Tabel. 1). Diperkirakan daun muda menjadi lebih menarik bagi herbivor karena memiliki kandungan nutrisi yang lebih baik dibanding daun tua. Aide (1993) menyatakan pada umumnya herbivori daun muda lebih besar dibandingkan dengan daun tua. Selain itu daun muda mempunyai kandungan serat yang lebih rendah dibandingkan daengan daun tua, sehingga daun muda mempunyai kandungan serat yang lebih rendah dibandingkan dengan daun tua, sehingga daun muda lebih disukai untuk dikonsumsi (Cooke et al., 1984). Pribadi (1998) menyatakan daun muda kemungkinan lebih enak dan disukai oleh herbivor karena kandungan nitrogennya lebih tinggi, banyak mengandung air, lunak, dan gampang dicerna. Franswoht dan Ellison (1993) menyatakan bahwa secara umum kualitas nutrisi memperlihatkan penurunan pada usia yang lebh tua, sehingga daun tua kurang disukai herbivor.

Palatability daun diduga juga berpengaruh terhadap tingkat herbivori. Herbivor akan menyukai daun dengan nutrisi dan kelezatan yang lebih tinggi. Daun muda terletak lebih terbuka dibanding daun tua sehingga lebih banyak terkena sinar matahari. Berdasarkan sifat sensitifnya terhadap sinar matahari maka daun yang mendapat cahaya matahari lebih besar akan menghasilkan produk fotosintesis yang lebih tinggi pula. Hal ini sesuai dengan pernyataan Basset (1991), yang menyatakan bahwa tumbuhan yang kanopinya lebih tinggi memperoleh sinar matahari lebih banyak sehingga kandungan nutrisi dan nitrogennya lebih tinggi dan lebih palatable sehingga disukai herbivor.

Hasil uji statistik dengan uji $F$ perbedaan stasiun pengambilan sampel terhadap tingkat herbivori daun $A$. corniculatum dan $R$. apiculata sama sangat perbengaruh terhadap tingkat herbivori. Sedangkan hasil uji statistik dengan uji $t$ pada ketiga spesies lainnya A. marina, C. tagal, dan S. caseolaris perbedaan tempat pengambilan sampel daun mangrove antar spesies yang sama tidak perpengaruh terhadap tingkat herbivori.

\section{K E S I M P U L A N}

Terdapat 3 variasi morfometri yang terbentuk dari kelima spesies dilihat dari nilai kumulatif dan selang kelas. Melihat dari banyaknya variasi yang terbentuk dapat dikatakan kondisi perairan di Segara Anakan Cilacap kurang baik. Rata-rata tingkat herbivori berturut-turut dari yang tertinggi hingga terendah adalah: A. marina $(7,46 \%), S$. caseolaris $(6,91 \%), R$. apiculata (4,08\%), A. corniculatum $(3,42 \%)$, dan $C$. tagal $(3,0 \%)$. Perbedaan spesies dan umur daun mempengaruhi tingkat herbivori.

\section{DAFT AR REFERENS I}

Ardli ER, Yani E, Widyastuti A. 2010. Distribusi spasial dan dinamika populasi Polymesoda erosa di ekosistem mangrove Segara Anakan Cilacap, sebagai acuan restocking dan konservasi. Fakultas Biologi Universitas Jenderal Soedirman. Purwokerto.

Barret GW, Rossenberg. 1981. Sterss effect on natural ecosystem. New York: John Wiley \& Sons Ltd.

Basset Y. 1991. The spatial distribution of herbivory, mines and galls within an Australia rain forest trees. Biotropica. 23(3):271-281.

Borazan A, Babac MT. 2003. Morphopetric leaf variation in Oaks (Quercus) of Bolu Turkey-Ann. Bot. Fennici. 40: 233-242.

Cooke FP, Brown JP, Mole S. 1984. Herbivore enzyme inhibitor, nitrogen and leaf structure of young and mature leaves in a tropical forest. Biotropica. 16(4):257-263.

Franswoth EJ, Ellison AM. 1993. Pattern of herbivory in Belizean mangrove swamps. Biotropica. 23(4b):555-565.

Hadi M, Tarwtjo U, Rahadian R. 2003. Buku Ajar: Biologi Insekta. Semarang: FMIPA Universitas Diponegoro.

Johnstone IM. 1981. Consumption of leaves by herbivores in mixed mangrove stands. Biotropica. 13(4):252-29.

Khusna E. 2008. Studi morfometri dan tingkat herbivori daun mangrove Rhizophora mucronata Lamk dan Avicennia marina (Forsk) Vierh di Kecamatan Legon Kulon dan Pusakanegara, Subang, Jawa Barat. [Skripsi]. FPIK Universitas Diponegoro. Semarang.

Lowman MD. 1983. An Assessment of techniques for measuring herbivory: is rainforest defoliation more intense than we thought. Biotropica. 16(4):264-268.

Murphy DH. 1990. The natural history of insect herbivory on mangrove in near Singapore. Raffles Bulletin of Zoology. 38(2):119-203.

Newbery DM, De Foresta H. 1985. Herbivory and defense in pioneer, gap and understory trees of tropical rain forest in French Guiana. Biotropica. 17:238-244

Noughton SJ. 1983. Compensatory plant growth as a response to herbivory. Oikos. 40:329-336.

Nurakhman. 2002. Kondisi Ekosistem mangrove berdasarkan indikator kualitas lingkungan dan pengukuran morfometrik daun di kawasan hutan lindung Angke-Kapuk, Jakarta Utara [skripsi]. Universitas Diponegoro-Semarang.

Nybakken J.W. 1992. Biologi Laut: Suatu pendekatan ekologis [diterjemahkan oleh Eidman M, Koesoebiono DG, Bengen MH, Subarjo S]. Jakarta: PT Gramedia Pustaka Utama..

Onuf CF, Teal JM, Valiela I. 1997. Interaction of nutrients, plant growth and herbivory in a mangrove ecosytem. Ecology. 58:514-526.

Pribadi R. 1998. The ecology of mangrove vegetation in Bintuni Bay, Irian Jaya, Indonesia [thesis]. Departemen of Biological and Molecular Sciences University of Stirling-Scotland.

Saenger P. 2002. Mangrove ecology, silviculture and conservation. London: Kluwer Academic Publisher.

Stowe KA. 1995. Intracrown distribution of herbivory damage on Laguncularia racemosa in tidally influenced riparian habitat. Biotropica. 27(4):509-512.

Yuwono E, Jennerjahn TC, Nordhaus I, Ardli ER, Sastranegara MH, Pribadi R. 2007. Ecological status of Segara Anakan, Indonesia: A mangrove-fringed Lagoon affected by human activities. Asian Journal of Water, Environment and Pollution. 4(1):61-70. 